\title{
Application of neurohabilitation therapy in a six-month-old pediatric patient as a treatment for neurodevelopmental delay (clinical case)
}

\section{Aplicación de terapia neurohabilitatoria en paciente pediátrico de seis meses como tratamiento para el retraso en su neurodesarrollo (caso clínico)}

BOLAÑOS-AGUILAR, Jimena*†, SUBERVIER-ORTIZ, Laura and CORTÉS-MÁRQUEZ, Sandra Kristal

Universidad Politécnica de Pachuca, Physical Therapy, Mexico.

ID 1 ${ }^{\text {st }}$ Author: Jimena, Bolaños-Aguilar / ORC ID: 0000-0001-9659-4269, Researcher ID Thomson: ABC-9915-202

ID $1^{\text {st }}$ Co-author: Laura, Subervier-Ortiz / ORC ID: 0000-0001-5350-127X, Researcher ID Thomson: V-5627-2018

ID $2^{\text {nd }}$ Coauthor: Sandra Kristal, Cortés-Márquez / ORC ID: 0000-0002-2218-8740, Researcher ID Thomson: V-57362018, CVU CONACYT ID: 395488

DOI: $10.35429 / J P .2021 .13 .5 .1 .4$

Received January 10, 2021; Accepted June 30, 2021

\section{Abstract}

Objectives: To stop the neurodevelopmental delay of a sixmonth-old pediatric patient through the application of Neurohabilitation Therapy. To analyze the evolution with early detection, adherence to treatment and the participation of the baby's family nucleus, for the improvement of his neurodevelopment. To demonstrate the efficiency of the application of Neurohabilitation Therapy in six-month-old pediatric patients. Methodology: Type of study: quasi-experimental descriptive study with quantitative approach and prospective longitudinal design. Contributions: The treatment was efficient to stop neurodevelopmental delay, negative responses were obtained in $3 / 3$ reflexes at spinal level, 8/8 reflexes at brain stem level, in automatic movement reactions $2 / 3$ negative responses and $1 / 3$ positive response. According to Amiel Tison's neurological examination of the 1 st year of life, scores of 0 were obtained in cranial growth, relational life, passive tone, motor skills and primary reflexes, indicating that the infant's neurodevelopment is normal according to age.

Early intervention, Neurohabilitation therapy, Neurodevelopment

\section{Resumen}

Objetivos: Frenar el retraso del neurodesarrollo de un paciente pediátrico de seis meses de edad a través de la aplicación de Terapia Neurohabilitatoria. Analizar la evolución con la detección temprana, la adhesión al tratamiento y la participación del núcleo familiar del bebé, para la mejora en su neurodesarrollo. Demostrar la eficiencia de la aplicación de Terapia Neurohabilitatoria en paciente pediátrico de seis meses de edad. Metodología: Tipo de estudio: cuasi experimental de alcance descriptivo con enfoque cuantitativo y diseño longitudinal prospectivo. Contribuciones: El tratamiento fue eficiente para frenar el retraso del neurodesarrollo, se obtuvieron respuestas negativas en $3 / 3$ reflejos a nivel espinal, $8 / 8$ reflejos a nivel de tallo cerebral, en reacciones de movimientos automáticos $2 / 3$ respuestas negativas y $1 / 3$ respuesta positiva. De acuerdo con la exploración neurológica del $1^{\circ}$ de vida de Amiel Tison se obtuvieron puntuaciones de 0 en crecimiento craneal, vida relación, tono pasivo, motricidad y reflejos primarios, lo que indica que el neurodesarrollo del bebé es normal conforme a la edad.

Intervención temprana, Terapia neurohabilitatoria, Neurodesarrollo

Citation: BOLAÑOS-AGUILAR, Jimena, SUBERVIER-ORTIZ, Laura and CORTÉS-MÁRQUEZ, Sandra Kristal. Application of neurohabilitation therapy in a six-month-old pediatric patient as a treatment for neurodevelopmental delay (clinical case). Journal of Physiotherapy and Medical Technology. 2021. 5-13:1-4.

\footnotetext{
* Author Correspondence (E-mail: jime0510@ outlook.com).

$\uparrow$ Researcher contributing as first author.
} 


\section{Introduction}

Neurodevelopment is defined as the process of acquisition of maturational skills in the child and is determined by biological and environmental aspects in constant interaction. It corresponds both to the maturation of nervous structures and to the learning produced by the child as he discovers himself and his environment (Oliva, 2020).

The central nervous system develops from the first weeks of gestation, a process influenced by multiple organic, social and environmental factors. Postnatal social experiences arise from the relationships that the child establishes from an early age with the community and culture where he/she lives, have a strong impact on the developmental process and should be considered as transcendent in pediatric practice (Oliva, 2020).

The assessment of developmental milestones in the child is important as it allows estimating that brain development is occurring within an appropriate framework, therefore, it is very important to know the minimum developmental assessment parameters for each age (Medina, 2015).

Worldwide 162 million children did not reach a full development of their abilities, in Mexico mild neurodevelopmental delay occurred in $32.1 \%$, moderate delay in $21.9 \%$ and severe delay in $17.2 \%$ in a sample of 37,495 children between 11 and 13 months of age (Avila, 2018).

Currently, in Mexico, 20\% of all disabilities are related to neurological problems caused during or around birth (Fundación UNAM, 2020).

That is why the present project exposes the clinical case of a six-month-old pediatric patient with neurodevelopmental delay, a physiotherapeutic treatment based on Neurohabilitation Therapy and use of textures of the Rood Method was used to normalize muscle tone with the aim of reducing the delay in his neurodevelopment. Neurohabilitation is a therapeutic diagnostic method that is used early during the first postnatal months and is recommended mainly in infants exposed to prenatal and perinatal risk factors that may develop brain damage.
It is mainly based on the development of the nervous system and the plasticity of the immature brain that allows through physical examination the diagnosis, treatment and clinical follow-up to minimize the manifestation of brain injuries of perinatal origin (Barrera, 2010).

\section{Methodology}

A quasi-experimental study of descriptive scope with a quantitative approach and prospective longitudinal design was carried out.

\section{Study area}

Universe: Comprehensive Rehabilitation Center of Hidalgo (CRIH). Population: Multiple Early Multiple Stimulation Area. Sample: 6-monthold pediatric patient with neurodevelopmental delay.

\section{Results}

The application of Neurohabilitation Therapy in a 6-month-old pediatric patient as a treatment for retardation was efficient obtaining the following results: negative responses in $3 / 3$ reflexes at spinal level and 8/8 reflexes at brain stem level, in automatic movement reactions $2 / 3$ negative responses and $1 / 3$ positive response.

According to the neurological examination of the first year of life by Amiel Tison, which evaluates five criteria, he obtained code 0 in cranial growth, relational life (alertness and attention, visual tracking, excitability), passive tone, motor skills and primary reflexes, which indicates that the neurodevelopment of the baby is normal according to the age of the patient.

It is of utmost importance the continuity of therapies and the participation of the family nucleus. 


\section{Annexes}

\begin{tabular}{|c|c|c|}
\hline Reflexes & $\begin{array}{c}\text { Initial } \\
\text { assessment (6 } \\
\text { months) }\end{array}$ & $\begin{array}{c}\text { Final } \\
\text { assessment (7 } \\
\text { months) }\end{array}$ \\
\hline \multicolumn{3}{|l|}{ Spinal level } \\
\hline $\begin{array}{l}\text { Flexor } \\
\text { retraction }\end{array}$ & Positive & Negative \\
\hline $\begin{array}{l}\text { Reflex } \\
\text { extension }\end{array}$ & Positive & Negative \\
\hline Cross extension & Positive & Negative \\
\hline \multicolumn{3}{|c|}{ Brain stem level } \\
\hline $\begin{array}{l}\text { Asymmetric } \\
\text { neck tonic }\end{array}$ & Positive & Negative \\
\hline $\begin{array}{l}\text { Symmetric } \\
\text { neck tonic } 1\end{array}$ & Positive & Negative \\
\hline $\begin{array}{l}\text { Symmetric } \\
\text { neck tonic } 2\end{array}$ & Negative & Negative \\
\hline $\begin{array}{l}\text { Supine } \\
\text { labyrinthine } \\
\text { tonic }\end{array}$ & Positive & Negative \\
\hline $\begin{array}{l}\text { Prone } \\
\text { labyrinthine } \\
\text { tonic }\end{array}$ & Positive & Negative \\
\hline $\begin{array}{l}\text { Associated } \\
\text { reactions }\end{array}$ & Negative & Negative \\
\hline $\begin{array}{l}\text { Positive support } \\
\text { reaction }\end{array}$ & Positive & Negative \\
\hline $\begin{array}{l}\text { Negative } \\
\text { support reaction }\end{array}$ & Negative & Negative \\
\hline \multicolumn{3}{|c|}{ Automatic movement reactions } \\
\hline Moro reflex & Positive & Negative \\
\hline Landau reflex & Negative & Positive \\
\hline $\begin{array}{l}\text { Extensor } \\
\text { defense reflex }\end{array}$ & Negative & Positive \\
\hline
\end{tabular}

Table 1 Initial and final evaluation of reflex examination guide

\begin{tabular}{|c|c|c|}
\hline Sections & $\begin{array}{l}\text { Examination } \\
\text { at } 6 \text { months }\end{array}$ & $\begin{array}{l}\text { Examination } \\
\text { at } 7 \text { months }\end{array}$ \\
\hline $\begin{array}{l}\text { Cranial growth (pc, } \\
\text { growth profile, } \\
\text { fontanelles } \\
\text { sutures) }\end{array}$ & 1 & 0 \\
\hline $\begin{array}{lr}\begin{array}{l}\text { Relational } \\
\text { (alertness }\end{array} & \begin{array}{r}\text { life } \\
\text { and }\end{array} \\
\text { attention, fixation } \\
\text { and visual tracking, } \\
\text { excitability) }\end{array}$ & 1 & 0 \\
\hline $\begin{array}{l}\text { Passive tone (body } \\
\text { axis and limbs) }\end{array}$ & 0 & 0 \\
\hline $\begin{array}{l}\text { Motricity } \\
\text { (quantitative and } \\
\text { qualitative aspects) }\end{array}$ & 1 & 0 \\
\hline $\begin{array}{lr}\begin{array}{l}\text { Primary } \\
\text { (sucking }\end{array} & \text { reflexes } \\
\text { only) } & \\
\end{array}$ & $\mathrm{x}$ & 0 \\
\hline Head control & 1 & 0 \\
\hline Result & $\begin{array}{l}\text { Moderate } \\
\text { deficit }\end{array}$ & Normal \\
\hline
\end{tabular}

Table 2 Neurological Examination first year of life Amiel Tison

\begin{tabular}{|c|c|}
\hline $\begin{array}{c}\text { Mobilizations and } \\
\text { sensory stimulation of } \\
\text { upper and lower limbs }\end{array}$ & Exercises \\
\hline $\begin{array}{l}5 \text { times each } \\
\text { Sensory stimulation } \\
\text { Use of sensory gloves } \\
\text { starting with five soft } \\
\text { textures with distal to } \\
\text { proximal direction of } \\
\text { lower limbs and upper } \\
\text { limbs. }\end{array}$ & $\begin{array}{l}18 \text { neurohabilitation } \\
\text { therapy exercises are } \\
\text { performed } 3 \text { to } 4 \text { times. } \\
\text { - Neck control exercises } \\
\text { (7) } \\
\text { - Exercises for bearings } \\
\text { (3) } \\
\text { - Exercises for lateral and } \\
\text { anterior protections (2) } \\
\text { - Exercises for sitting (3) } \\
\text { - Exercises for crawling in } \\
\text { ascending and descending } \\
\text { plane (3) }\end{array}$ \\
\hline
\end{tabular}

Table 3 Exercises used in Neurohabilitation Therapy and sensory stimulation

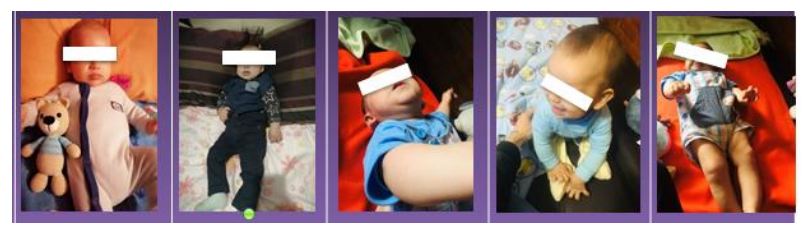

a) Six-month-old pediatric patient undergoing neurohabilitation therapy.

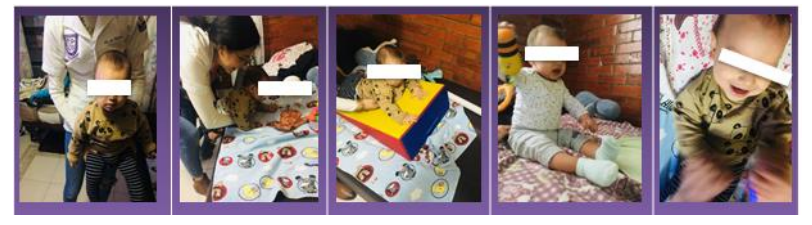

b) Seven-month-old pediatric patient at one month of reevaluation.

Figure 1 Evidence of initial and final assessment

\section{Conclusions}

The application of Neurohabilitation Therapy in a six-month-old pediatric patient to stop neurodevelopmental delay was effective. Eighteen exercises of Neurohabilitation Therapy were applied by means of establishing postures, movements and normalization of muscle tone. The changes were evaluated by means of the reflex guide scale where negative results were obtained in the two levels of maturation of the central nervous system, spinal and brain stem level.

On the other hand, with the Amiel Tison neurological examination, the results showed a result with codes 0 in the six criteria to evaluate cranial growth, relationship life, passive tone, primary reflexes and head control, which represents a typical aspect for the age, within the limits of normality. 
The infant achieved head control, increased head circumference, turning, sitting position, lateral and anterior defenses, gaze tracking, transition of objects from one hand to another and attachment to parents.

Thanks to the treatment, it contributed to the improvement of the plasticity of the immature central nervous system, since, through physical examination, diagnosis, treatment and clinical follow-up, it minimizes the manifestations of brain lesions of perinatal origin. (Barrera, 2010)

\section{References}

Ávila A; Álvarez M; Galindo C. (2018). "Retraso del Neurodesarrollo, Desnutrición y Estimulación Oportuna en Niños Rurales Mexicanos". Acta de Investigación Psicológica. Vol. 8(3). (pp.6-16).

Barrera, JE. (2010). Terapia Neurohabilitatoria. UNAM. México.69.

Fundación Unam. (2020) (September 01, 2020) Available at: https://www.fundacionunam.org.mx/tratamient o-neurologico-para-bebes/.Consultado el 01 de septiembre de 2020.

Medina MP; Kahn C; Muñoz P; Leyva J; Moreno J. (2015). "Neurodesarrollo infantil: características normales y signos de alarma en el niño menor de cinco años". Rev Perú. Vol. 32 (3). (pp. 565-573).

Oliva C; Vitale MP; Grañana N; Rouvier ME; Zeltman C. (2020). "Evolución del neurodesarrollo con el uso del cuestionario de edades y etapas ASQ-3 en el control de salud de niños". Rev Neurol. Vol. 70 (01). (pp. 12-18). 